\title{
Population density of Arabica coffee cultivars for bean quality and yield ${ }^{1}$
}

\author{
Jane Maria de Carvalho Silveira², Maurício Dominguez Nasser ${ }^{3}$, \\ Flávia Aparecida de Carvalho Mariano-Nasser ${ }^{4}$, Maximiliano Kawahata Pagliarini ${ }^{5}$, Gerson Silva Giomo ${ }^{6}$
}

\section{ABSTRACT}

For the implantation of a coffee tree crop, aiming at a high yield, each cultivar, depending on the plant distribution and density, can express differently its results. This study aimed to evaluate the yield potential and grain quality of Arabica coffee cultivars grown under different spacings between rows and between plants. A randomized block design was used, with three replications, in a split-split-plot scheme, being the plots three coffee cultivars (Obatã IAC-1669-20, Tupi IAC-1669-33 and Catuaí Vermelho IAC-144), four spacings between rows (1.8 m, $2.0 \mathrm{~m}, 2.5 \mathrm{~m}$ and $3.0 \mathrm{~m})$ and four spacings between plants in the row $(0.5 \mathrm{~m}, 0.7 \mathrm{~m}, 0.8 \mathrm{~m}$ and $1.0 \mathrm{~m})$, totaling 48 treatments. The type of coffee bean (flat, peaberry and elephant) and yield per hectare were evaluated. The Obatã cultivar showed the highest potential yield, in relation to Tupi and Catuaí Vermelho, and also the highest percentage of flat grains. The factors, in order of importance, that interfere with the potential yield of processed coffee are the cultivar and the spacing between rows and between plants.

KEYWORDS: Coffea arabica; coffee growing; morphological characteristics of coffee trees.

\section{INTRODUCTION}

In coffee cultivation, spacing determines the number of plants per area and is based on the spacing between rows multiplied by the spacing between plants in the row. Depending on the growing conditions, the plant population density can significantly modify the yield of coffee beans.

Coffee crops are highly influenced by the interaction genotype-environment. The yield reached

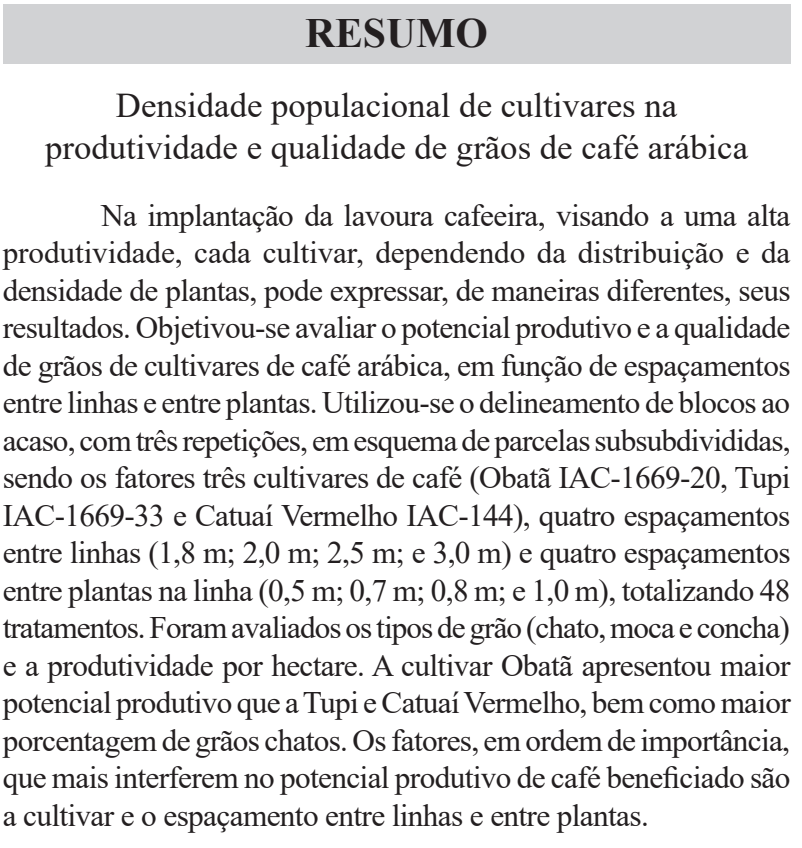

PALAVRAS-CHAVE: Coffea arabica; cafeicultura; características morfológicas de cafeeiro.

by a given cultivar is related, in addition to other technical aspects, to the adopted spacing. According to Pereira et al. (2011), reducing the spacing between rows and between plants in the row results in increased coffee yields. The number and distribution of plants are decisive to obtain high coffee yields and should be considered in the adoption of spacings for coffee crops.

Given that coffee crops in Brazil are grown in extensive areas, there can be several coffee

1. Received: Apr. 20, 2018. Accepted: Jul. 23, 2018. Published: Oct. 11, 2018. DOI: 10.1590/1983-40632018v4852589.

2. Agência Paulista de Tecnologia dos Agronegócios, Mococa, SP, Brasil. E-mail/ORCID: jane@iac.sp.gov.br/0000-0003-2502-8790.

3. Agência Paulista de Tecnologia dos Agronegócios, Polo Regional Alta Paulista, Adamantina, SP, Brasil. E-mail/ORCID: mdnasser@apta.sp.gov.br/0000-0002-4239-5958.

4. Universidade Estadual Paulista, Faculdade de Ciências Agronômicas, Departamento de Horticultura, Botucatu, SP, Brasil. E-mail/ORCID: flaviamariano1@hotmail.com/0000-0002-9276-7983.

5. Universidade Federal da Grande Dourados, Dourados, MS, Brasil. E-mail/ORCID: mpagliarini@ufgd.edu.br/0000-0001-7408-6327. 6. Agência Paulista de Tecnologia dos Agronegócios, Centro de Café, Campinas, SP, Brasil. 
production systems using different spacings and a different number of plants, when the coffee crops are started. This implies a yield variation in several production regions, frequently resulting in a low expression of the genetic potential of the cultivar selected for planting.

According to Ferraz et al. (2012), coffee growing in Brazil takes place in environments with a great diversity of climate, soil, relief, physiological characteristics (cultivar, age, skirt and crown diameter, fruit color, etc.), phytosanitary infestations and crop managements (cropping systems, irrigation, mechanization, fertilization and spraying). The diversity of these factors may strongly influence coffee yields, and even crop management, when carried out in a homogeneous way, and reduce the rural producers' profitability.

For Siqueira et al. (1985) and Sakai et al. (2013 and 2015), increased coffee yields can be reached by an increase per area unit, followed by an increase in plant population, mainly in the first harvests.

In Colombia, Uribe \& Mestre (1988) observed that a population of 10,000 plants $\mathrm{ha}^{-1}$, with the use of one, two or three plants per pit and differentiated spacing, provided the maximum yield. According to Scaranari \& Nogueira Neto (1963) in Brazil, and Mitchell (1976) in Kenya, a density of 5,000 plants ha- ${ }^{-1}$ provided the highest yield, while Rodriguez et al. (1966), in Puerto Rico, found the best density using 6,000 plants $\mathrm{ha}^{-1}$; however, Hangdong \& Bartolomeu (1966) showed a population of 3,333 plants ha ${ }^{-1}$ as the most adequate one.

Considering that smaller spacings are mainly adopted to increase the coffee yield per area, it is important to emphasize that changes in spacings can generate differentiated results in coffee cultivars, interfering in crop practices, as well as stressing the need for programmed pruning. In addition, if the plant yield potential is not exploited, the production costs may increase.

As a result of this search for a greater yield and competitiveness in the coffee agribusiness, Oliveira et al. (2010) observed the use of innovative production systems in the sector, seeking to increase the competitiveness through market differentiation for quality.

According to Silveira et al. (2015), for the coffee bean size of the Obatã cultivar, under dry conditions and first production, $42 \%$ of the grains were larger than $16 \mathrm{~mm}$ with conventional fertilization, while, under fertigation, this percentage was more than $75 \%$.

Thus, the present study aimed to evaluate the yield and grain quality of three small size Arabica coffee cultivars in different planting spacings.

\section{MATERIAL AND METHODS}

The experiment was conducted at an experimental area of the Fundação de Pesquisa e Difusão de Tecnologia Agrícola Luciano Ribeiro da Silva, in São José do Rio Pardo, São Paulo state, Brazil (21 $37^{\prime} 16$ 'S, 46 $6^{\circ} 53^{\prime} 15^{\prime \prime} \mathrm{W}$ and $750 \mathrm{~m}$ of altitude).

A randomized complete block design, with three replicates, was used in a split-split-plot factorial scheme. Three cultivars of Arabica coffee under dry conditions were evaluated, of which two were resistant to rust (Obatã IAC-1669-20 and Tupi IAC-1669-33) and one susceptible to rust (Catuaí Vermelho IAC-144). The seedlings were planted in 2004 , at four spacings between rows $(1.80 \mathrm{~m}, 2.00 \mathrm{~m}$, $2.50 \mathrm{~m}$ and $3.00 \mathrm{~m})$ and four spacings between plants in the row $(0.50 \mathrm{~m}, 0.70 \mathrm{~m}, 0.80 \mathrm{~m}$ and $1.00 \mathrm{~m})$, with one plant per plot, totaling 48 treatments.

The fertilizations at implantation, formation and production were performed according to the recommendations proposed by Raij et al. (1997). Yield was evaluated at the first three harvests: 2005/2006, 2006/2007 and 2007/2008.

Yield was evaluated based on the amount of fruits (cherries, green and withered berries) harvested manually in plants from the useful area of each plot. After that, a sample of $2.0 \mathrm{~kg}$ of berries was collected and stored in plastic net bags for sun drying. After the drying period, the samples were processed and weighed, thus producing the data used to calculate the coffee yield.

A grain quality evaluation was performed only for the 2008 harvest. Samples of $100 \mathrm{~g}$ of each treatment were collected, manually separated and sorted by flat, peaberry and elephant beans, and then weighed separately. According to the ABIC (2013), flat grains have a convex dorsal surface and ventral plane or slightly concave, with a central groove in the longitudinal direction - these are considered normal for coffee. The peaberry type has an ovoid shape and a central groove in the longitudinal direction. Elephant grains have a shell shape resulting from the separation of imbricated grains resulting from fertilization of two ova in a single ovary. 
The data were submitted to analysis of variance, applying the $F$ test to verify significant differences among the treatments, and the Tukey test at $5 \%$ of significance to compare means.

\section{RESULTS AND DISCUSSION}

The interactions of spacing between either rows, plants or cultivars were not significant for the characteristics evaluated using the F test at $5 \%$ of significance (Table 1). This same result was found in the interactions spacing-between-rows $\mathrm{x}$ spacingbetween-plants, and spacing-between-plants $\mathrm{x}$ spacing-between-cultivars. However, the analysis of spacings between rows and between cultivars showed a significant difference in the percentage of flat grains (of greater commercial interest) and in yield, with a tendency of increased yields as the spacing between rows decreases, regardless of the cultivar. The spacing between rows of $1.80 \mathrm{~m}$ showed a superior yield, if compared to those of $2.50 \mathrm{~m}$ and $3.00 \mathrm{~m}$, reaching up to $54 \%$ more, in terms of yield.

The spacing between rows, between plants and between cultivars, in isolation, showed a significant difference by the $\mathrm{F}$ test at $5 \%$ of significance. A higher percentage, regarding the spacing between plants of $0.50 \mathrm{~m}$, was observed for flat-type grains, when compared to the spacing between plants of $1.0 \mathrm{~m}$; and the Obatã cultivar was superior to Catuaí Vermelho and Tupi, both in terms of flat grains and yield. This finding may be explained by the intrinsic genetic aspect of this cultivar, which is considered a hybrid plant, and it is probably more adapted to the climate of the region under study.

For the $3.00 \mathrm{~m}$ spacing between rows, there was a lower percentage of flat grains, in relation to other spacings (Table 1). As for the peaberry-type grains (of lower economic interest), the highest percentage was observed also for the $3.00 \mathrm{~m}$ spacing, to the detriment of the others. In relation to spacing between plants, a similar behaviour was observed to spacing between rows, in which the mean values of flat grains were lower in the larger spacings between plants $(0.80 \mathrm{~m}$ and $1.00 \mathrm{~m})$.

Regarding cultivars, Fazuoli (1986) indicates that the percentages of normal seeds of the flat type should range between $82.3 \%$ and $89.1 \%$, values that are higher than those found in the present study.

Table 1. Mean values for coffee characteristics of the cultivars Obatã, Catuaí Vermelho and Tupi, grown under different combinations of spacings between either rows (BR) and plants (BP) or cultivars, and yield.

\begin{tabular}{|c|c|c|c|c|}
\hline \multirow{2}{*}{ Treatments } & \multicolumn{3}{|c|}{ Processed coffee beans (\%) } & \multirow{2}{*}{ Yield $\left(\mathrm{kg} \mathrm{ha}^{-1}\right)$} \\
\hline & Flat & Peaberry & Elephant & \\
\hline \multicolumn{5}{|l|}{$\mathrm{BR}(\mathrm{m})$} \\
\hline 1.80 & $64.64 \mathrm{ab}$ & $22.90 \mathrm{~b}$ & $12.47 \mathrm{a}$ & $4,180.20 \mathrm{a}$ \\
\hline 2.00 & $65.95 \mathrm{a}$ & $23.38 \mathrm{~b}$ & $10.67 \mathrm{a}$ & $4,086.00 \mathrm{ab}$ \\
\hline 2.50 & $64.04 \mathrm{ab}$ & $23.30 \mathrm{~b}$ & $12.66 \mathrm{a}$ & $2,715.00 \mathrm{c}$ \\
\hline 3.00 & $62.69 \mathrm{~b}$ & $25.89 \mathrm{a}$ & $11.42 \mathrm{a}$ & $3,184.80 \mathrm{bc}$ \\
\hline \multicolumn{5}{|l|}{$\mathrm{BP}(\mathrm{m})$} \\
\hline 0.50 & $65.38 \mathrm{a}$ & $23.06 \mathrm{~b}$ & $11.56 \mathrm{a}$ & $932.40 \mathrm{a}$ \\
\hline 0.70 & $65.20 \mathrm{a}$ & $23.21 \mathrm{~b}$ & $11.59 \mathrm{a}$ & $3,559.20 \mathrm{ab}$ \\
\hline 0.80 & $64.31 \mathrm{ab}$ & $23.55 \mathrm{ab}$ & $12.14 \mathrm{a}$ & $3,424.80 \mathrm{ab}$ \\
\hline 1.00 & $62.41 \mathrm{~b}$ & $25.66 \mathrm{a}$ & $11.92 \mathrm{a}$ & $3,249.60 \mathrm{~b}$ \\
\hline \multicolumn{5}{|l|}{ Cultivars (VAR) } \\
\hline Obatã & $67.12 \mathrm{a}$ & $22.89 \mathrm{~b}$ & $9.99 \mathrm{~b}$ & $45.00 \mathrm{a}$ \\
\hline Catuaí Vermelho & $61.18 \mathrm{c}$ & $27.33 \mathrm{a}$ & $11.50 \mathrm{~b}$ & $2,444.40 \mathrm{~b}$ \\
\hline Tupi & $64.69 \mathrm{~b}$ & $21.38 \mathrm{~b}$ & $13.93 \mathrm{a}$ & $2,735.40 \mathrm{~b}$ \\
\hline $\mathrm{F}(\mathrm{BR})$ & $3.44^{*}$ & $4.05 * *$ & $2.91 *$ & $17.95 * *$ \\
\hline $\mathrm{F}(\mathrm{BP})$ & $3.47 *$ & $3.20^{*}$ & $0.26^{*}$ & $2.99 *$ \\
\hline $\mathrm{F}(\mathrm{VAR})$ & $22.36 * *$ & $27.62 * *$ & $17.57 * *$ & $129.79 * *$ \\
\hline $\mathrm{F}(\mathrm{BR} * \mathrm{BP})$ & $1.07^{\mathrm{ns}}$ & $0.66^{\mathrm{ns}}$ & $1.33^{\mathrm{ns}}$ & $0.56^{\mathrm{ns}}$ \\
\hline $\mathrm{F}(\mathrm{BR} * \mathrm{VAR})$ & $2.75^{*}$ & $1.47^{\mathrm{ns}}$ & $2.30^{\mathrm{ns}}$ & $5.34 * *$ \\
\hline $\mathrm{F}(\mathrm{BP} * \mathrm{VAR})$ & $0.81^{\mathrm{ns}}$ & $1.46^{\mathrm{ns}}$ & $0.49^{\text {ns }}$ & $1.12^{\mathrm{ns}}$ \\
\hline $\mathrm{F}(\mathrm{BR} * \mathrm{BP} * \mathrm{VAR})$ & $0.66^{\mathrm{ns}}$ & $0.63^{\text {ns }}$ & $0.88^{\mathrm{ns}}$ & $0.82^{\text {ns }}$ \\
\hline $\mathrm{CV}(\%)$ & 6.80 & 17.07 & 27.81 & 28.41 \\
\hline
\end{tabular}


In relation to the elephant-type grains, no significant changes were observed in the mean values for spacings between rows and between plants; however, between cultivars, a percentage of larger elephant grains was observed for the Tupi cultivar.

The results showed a higher yield in densified spacings and also a higher percentage of flat grains and a lower percentage of peaberry grains. The more the spacings between rows and between plants in the row are reduced, the greater the number of flat beans and the fewer the peaberry grains, without altering the shell defect. Rezende et al. (2010) did not find significant differences in the processed coffee classification, when working with irrigation at different times, in Arabica coffee.

Higher yields were observed for Obatã, including the best grain quality, with $67.12 \%$ of flat grains, and the lowest average value for elephant grains $(9.99 \%)$. In addition to such an excellent yield, Obatã showed the highest presence of flat grains and fewer defects in the coffee beans. It is important to emphasize that the evaluation of grain quality was performed in 2008, a year of high yields.

Data for average processed coffee yields, at the first three harvests, and $\mathrm{F}$ test values for factors and their interactions are shown in Table 2. Yield was significantly affected by the evaluated production factors (spacings between rows, between plants and between cultivars); however, there was no significant interaction between these factors.

The yield of the three cultivars increased significantly by reducing the spacings between rows and between plants, with a more expressive effect for spacings between rows. This behaviour justifies the need for adjustments in the spacings for the implantation of small coffee crops, especially spacings between rows, in order to maximize the potential of cultivars, in order to obtain higher yields per cultivated area.

According to Matiello et al. (2010), in the last 30 years, there has been a tendency to distribute plants better along the row, at smaller distances, ranging from $0.5 \mathrm{~m}$ to $1.0 \mathrm{~m}$, with only one plant per pit. These authors verified an increase of $28 \%$ in the yield per area, as well as a reduction of yield per plant, thus reducing postharvest wear. On the other hand, they warn that it may increase the risk of rust attack and plant verging.

The highest processed coffee yield was observed in the first triennium, which was obtained

Table 2. Yield of processed coffee beans for the cultivars Obatã, Catuaí Vermelho and Tupi, grown in different combinations of spacing between rows (BR) and between plants (BP), in the first three harvests.

\begin{tabular}{|c|c|c|c|c|}
\hline \multirow{2}{*}{ Treatments } & \multicolumn{4}{|c|}{ Processed coffee beans yield $\left(\mathrm{kg} \mathrm{ha}^{-1}\right)$} \\
\hline & 2006 & 2007 & 2008 & Average \\
\hline \multicolumn{5}{|l|}{$\mathrm{BR}(\mathrm{m})$} \\
\hline 1.80 & $4,059.00 \mathrm{a}$ & $619.80 \mathrm{ab}$ & $4,180.20 \mathrm{a}$ & $2,953.20 \mathrm{a}$ \\
\hline 2.00 & $3,186.00 \mathrm{ab}$ & $519.60 \mathrm{~b}$ & $4,086.00 \mathrm{ab}$ & $2,597.40 \mathrm{ab}$ \\
\hline 2.50 & $2,245.20 \mathrm{~b}$ & $291.60 \mathrm{~b}$ & $2,715.00 \mathrm{c}$ & $1,750.80 \mathrm{c}$ \\
\hline 3.00 & $1,873.20 \mathrm{~b}$ & $933.60 \mathrm{a}$ & $3,184.80 \mathrm{bc}$ & $1,997.40 \mathrm{bc}$ \\
\hline \multicolumn{5}{|l|}{$\mathrm{BP}(\mathrm{m})$} \\
\hline 0.50 & $3,256.20 \mathrm{a}$ & $595.80 \mathrm{a}$ & $3,932.40 \mathrm{a}$ & $2,595.00 \mathrm{a}$ \\
\hline 0.70 & $3,057.60 \mathrm{a}$ & $520.20 \mathrm{a}$ & $3,559.20 \mathrm{ab}$ & $2,379.60 \mathrm{ab}$ \\
\hline 0.80 & $2,748.60 \mathrm{a}$ & $583.80 \mathrm{a}$ & $3,424.80 \mathrm{ab}$ & $2,252.40 \mathrm{ab}$ \\
\hline 1.00 & $2,302.80 \mathrm{a}$ & $663.60 \mathrm{a}$ & $3,249.60 \mathrm{~b}$ & $2,071.80 \mathrm{~b}$ \\
\hline \multicolumn{5}{|l|}{ Cultivars (VAR) } \\
\hline Obatã & $3,315.00 \mathrm{a}$ & $508.20 \mathrm{a}$ & $5,445.00 \mathrm{a}$ & $3,088.20 \mathrm{a}$ \\
\hline Catuaí Vermelho & $2,631.00 \mathrm{a}$ & $600.60 \mathrm{a}$ & $2,444.40 \mathrm{~b}$ & $1,891.80 \mathrm{~b}$ \\
\hline Tupi & $2,578.80 \mathrm{a}$ & $665.40 \mathrm{a}$ & $2,735.40 \mathrm{~b}$ & $2,011.80 \mathrm{~b}$ \\
\hline $\mathrm{F}(\mathrm{BR})$ & $12.78 * *$ & $11.11 * *$ & $13.68 * *$ & $13.99 * *$ \\
\hline $\mathrm{F}(\mathrm{BP})$ & $4.34^{\mathrm{ns}}$ & $0.45^{\mathrm{ns}}$ & $4.38^{\mathrm{ns}}$ & $7.72 *$ \\
\hline F (VAR) & $6.2^{\mathrm{ns}}$ & $0.71^{\mathrm{ns}}$ & $38.18^{* *}$ & $56.29 * *$ \\
\hline $\mathrm{F}(\mathrm{BR} * \mathrm{BP})$ & $2.39^{\mathrm{ns}}$ & $0.40^{\mathrm{ns}}$ & $0.79^{\text {ns }}$ & $0.86^{\mathrm{ns}}$ \\
\hline $\mathrm{F}(\mathrm{BR} * \mathrm{VAR})$ & $0.68^{\mathrm{ns}}$ & $1.19^{\text {ns }}$ & $2.58^{\mathrm{ns}}$ & $2.25^{\mathrm{ns}}$ \\
\hline $\mathrm{F}(\mathrm{BP} * \mathrm{VAR})$ & $2.33^{\mathrm{ns}}$ & $1.63^{\mathrm{ns}}$ & $1.61^{\mathrm{ns}}$ & $1.52^{\mathrm{ns}}$ \\
\hline $\mathrm{F}(\mathrm{BR} * \mathrm{BP} * \mathrm{VAR})$ & $0.56^{\mathrm{ns}}$ & $1.23^{\mathrm{ns}}$ & $1.31^{\mathrm{ns}}$ & $0.97^{\mathrm{ns}}$ \\
\hline
\end{tabular}

Means followed by the same letter in the columns do not differ significantly from each other by the Tukey test at $5 \%$ or $1 \%$ of significance. $\mathrm{F}=\mathrm{F}$ test value for factors and interactions; ${ }^{\text {ns }}$ not significant; $*$ significant at $5 \%$ of probability; $* *$ significant at $1 \%$. 
using spacings of 1.80-2.0 m between rows and 0.5-0.7 $\mathrm{m}$ between plants. However, there was no significant difference for the spacings $0.5 \mathrm{~m}$, $0.7 \mathrm{~m}$ and $0.8 \mathrm{~m}$ between plants. It was noted that the smallest row spacing $(1.8 \mathrm{~m})$ provided a yield $47 \%$ higher than that obtained in the largest row spacing $(3.0 \mathrm{~m})$. Such a high yield is equivalent to approximately $960 \mathrm{~kg}$ of processed coffee per hectare, a significant value.

Sakai et al. (2015) evaluated the yield of Catuaí Amarelo coffee in different populations, with tworow spacings ( $1.6 \mathrm{~m}$ and $3.2 \mathrm{~m}$ ) and three spacings in the row $(0.50 \mathrm{~m}, 0.75 \mathrm{~m}$ and $1.00 \mathrm{~m})$, and concluded that the spacing of $1.6 \mathrm{~m}$ in the row presented the highest yield in first three production cycles.

The results indicated that smaller spacings between rows and between plants resulted in a coffee yield increment at the first harvest, what corroborates the results obtained by Paulo et al. (2005), who verified a linear yield increase for the cultivars Obatã and Catuaí Amarelo, with a planting density increase at the first two harvests.

In the average of three harvests, Obatã showed a yield superior to Tupi and Catuaí Vermelho, what indicates a greater yield potential in the first three years of production. The average yield obtained by Obatã in the first triennium was $3,060 \mathrm{~kg} \mathrm{ha}^{-1}$, above the average Brazilian yield. It is noteworthy that this cultivar yielded $63 \%$ and $53 \%$ more than Catuaí Vermelho and Tupi, respectively.

A maximum yield of $5,400 \mathrm{~kg}$ and a minimum one of $480 \mathrm{~kg} \mathrm{ha}^{-1}$ were observed for Obatã in 2008 and 2007, respectively, what can be attributed to a biennial yield oscillation, interspersing a low harvest with a high one. Considering that such behaviour was observed in the three cultivars, it can be inferred that the biennial yield in densified systems had already occurred since the first harvests.

Martins et al. (2015) evaluated a two-year coffee crop under dry conditions, which normally has a yield potential of $1,800 \mathrm{~kg} \mathrm{ha}^{-1}$. In comparison to the yield of 2014, this yield decreased to $774 \mathrm{~kg} \mathrm{ha}^{-1}$, and when adding losses in the picking process $(16 \%)$, the final yield was $648 \mathrm{~kg} \mathrm{ha}^{-1}$ - values below those found for the evaluated cultivars.

\section{CONCLUSIONS}

1. Reducing the spacings between rows and between plants provides an increase in the yield of processed coffee beans, for the cultivars Obatã, Tupi and Catuaí Vermelho, in the first three years of production;

2. Obatã showed a higher yield of processed coffee beans in the first triennium, if compared to Tupi and Catuaí Vermelho;

3. The factors that most affect the yield potential of processed coffee beans are, in order of importance, cultivar, spacing between rows and spacing between plants.

\section{REFERENCES}

ASSOCIAÇÃO BRASILEIRA DA INDÚSTRIA DO CAFÉ (ABIC). Glossário do café. 2013. Available at: $<$ http://www.abic.com.br/publique/cgi/cgilua.exe/sys/ start.htm?sid=36>. Access on: 09 Aug. 2013.

FAZUOLI, L. C. Genética e melhoramento do cafeeiro. In: RENA, A. B. et al. (Eds.). Cultura do cafeeiro: fatores que afetam a produtividade. Piracicaba: Associação Brasileira para Pesquisa da Potassa e do Fosfato, 1986. p. $87-113$.

FERRAZ, G. A. E. S. et al. Variabilidade espacial e temporal do fósforo, potássio e da produtividade de uma lavoura cafeeira. Engenharia Agrícola, v. 32, n. 1, p. 140150, 2012.

HANGDONG, A. S.; BARTOLOMEU, R. The effect of the spacing on the yield of Arabica coffee. Coffee and Cacao Journal, v. 9, n. 1, p. 10-18, 1966.

MARTINS, E. et al. Influência das condições climáticas na produtividade e qualidade do cafeeiro produzido na região do sul de Minas Gerais. Coffee Science, v. 10, n. 4, p. 499-506, 2015.

MATIELLO, J. B. et al. Cultura de café no Brasil: manual de recomendações. Rio de Janeiro: MAPA/Procafé, 2010.

MITCHELL, H. W. Research on close spacing for intensive coffee production in Kenya. Kenya Coffee, v. 41, n. 1, p. 124-137, 1976.

PAULO, E. M. et al. Comportamento de cultivares de cafeeiro em diferentes densidades de plantio. Bragantia, v. 64 , n. 3, p. 397-409, 2005.

PEREIRA, S. P. et al. Crescimento, produtividade e bienalidade do cafeeiro em função do espaçamento de cultivo. Pesquisa Agropecuária Brasileira, v. 46, n. 2, p. 152-160, 2011.

RAIJ, B. V. et al. Café. In: RAIJ, B. V. et al. (Eds.). Recomendações de adubação e calagem para o estado de São Paulo. Campinas: IAC/Fundag, 1997. p. 97-101. (Boletim técnico,100). 
REZENDE, F. C. et al. Cafeeiro recepado e irrigado em diferentes épocas: produtividade e qualidade. Coffee Science, v. 5, n. 3, p. 229-237, 2010.

RODRIGUEZ, S. J. et al. Effect of planting distances on shaded coffee yield in Puerto Rico. The Journal of Agriculture of the University of Puerto Rico, v. 50, n. 2, p. 82-86, 1966.

SAKAI, E. et al. Coffea arabica (cv. Catuaí) production and bean size under different population arrangements and soil water availability. Engenharia Agrícola, v. 33, n. 1, p. 145-156, 2013.

SAKAI, E. et al. Coffee productivity and root systems in cultivation schemes with different population arrangements and with and without drip irrigation. Agricultural Water Management, v. 148, n. 1, p. 16-23, 2015.

SCARANARI, H. J.; NOGUEIRA NETO, P. Efeito da densidade de plantio sobre a produção de café "Mundo Novo". Bragantia, v. 22, n. 1, p. 373-382, 1963.

SILVEIRA, J. M. C. et al. Produção e tamanho de grãos de café Coffea arabica L. (cv. Obatã) sob fertirrigação. Revista Brasileira de Agricultura Irrigada, v. 9, n. 4, p. 204-210, 2015.

SIQUEIRA, R. et al. Espaçamento e produtividade do cafeeiro. Londrina: Iapar, 1985. (Informe de pesquisa, 56).

URIBE, H. A.; MESTRE, A. M. Efecto de la densidad de población y de la disposición de los árboles en la producción de café. Cenicafé, v. 39, n. 2, p. 31-42, 1988. 